Jurnal Perikanan (2019) Volume 9. No. 2 : 144-152

DOI : https://doi.org/10.29303/jp.v9i2.160

\title{
PENGARUH PEMBERIAN PAKAN KULIT SAPI TERHADAP PERTUMBUHAN dan KELANGSUNGAN HIDUP BENIH LOBSTER PASIR (Panulirus homarus)
}

\section{THE INFLUENCE OF COW'S SKIN FEED ON GROWTH AND SUSTAINABILITY OF SAND LOBSTER SEEDS (Panulirus homarus)}

\author{
Sherina Aulia Ningtias ${ }^{1 *}$, Muhammad Junaidi ${ }^{1}$, Ibadur Rahman ${ }^{1}$ \\ ${ }^{1)}$ Program Studi Budidaya Perairan, Fakultas Pertanian, Universitas Mataram
}

\begin{abstract}
Abstrak
Penelitian ini bertujuan untuk mengetahui pengaruh pemberian kulit sapi terhap pertumbuhan dan kelangsungan hidup benih lobster pasir (panulirus homarus). Metode yang digunakan dalam penelitian itu yaitu metode experimental mengunakan rancangan acak kelompok (RAK), dengan 5 perlakuan yaitu pemberian $100 \%$ ikan rucah, $75 \%$ ikan rucah $+25 \%$ kulit sapi, 50\% ikan rucah $+50 \%$ kulit sapi, $25 \%$ ikan rucah $+75 \%$ kulit sapi dan $100 \%$ kulit sapi yang di ulang sebanyak 3 kali. pengamatan di lakukan selama 60 hari. parameter yang di amati meliputi pertumbuhan mutlak, laju pertumbuhan spesifik, rasio konversi pakan dan tingkat kelansungan hidup. Hasil penelitian menunjukkan bahwa pertumbuhan mutlak dan laju pertumbuhan spesifik tertinggi terdapat pada perakuan $3(50 \%$ ikan rucah $+50 \%$ kulit sapi), yang dimana memberikan pengaruh yang berbeda nyata $(\mathrm{P}<0,05)$. Berdasarkan penelitian ini, untuk menggunakan pakan dengan 50\% ikan rucah + $50 \%$ kulit sapi dan melakukan uji proksimat pada kulit sapi mentah dan rebus.
\end{abstract}

Kata Kunci : kulit sapi, benih lobster pasir, pertumbuhan, kelangsungan hidup

\begin{abstract}
This study aims to determine the effect of giving cow skin on growth and survival of lobster sand (Panulirus homarus). The method used in the study was an experimental method using a randomized block design (RCBD), with 5 treatments namely giving $100 \%$ trash fish, $75 \%$ trash fish $+25 \%$ cow skin, $50 \%$ trash fish $+50 \%$ cow skin, $25 \%$ fish trash $+75 \%$ cow leather and $100 \%$ cow leather repeated 3 times. observations carried out for 60 days. The parameters observed include absolute growth, specific growth rate, feed conversion ratio and survival rate. The results showed that absolute growth and the highest specific growth rate were found in rooting 3 (50\% trash fish $+50 \%$ cow skin), which had a significantly different effect $(\mathrm{P}<0.05)$. Based on this study, to use feed with $50 \%$ trash fish $+50 \%$ cow leather and perform proximate tests on raw and boiled cow skin.
\end{abstract}

Keywords: cowhide, sand lobster seed, growth, survival

\section{Pendahuluan}

Indonesia merupakan negara kepulauan yang memiliki laut lebih luas dibandingkan daratan, dengan memiliki 17.503 pulau yang tersebar diseluruh nusantara. Pada masing-masing pulau memiliki daya tarik tersendiri yang dapat

*Korespondensi:

sherinaauliant23@gmail.com dikembangkan untuk obyek wisata, kegiatan budidaya dan lain-lain. Salah satu pulau yang bersinergi antara pelaku wisata, kegiatan budidaya dan aktifitas nelayan tangkap dapat dijumpai di Pulau Lombok.

Lobster merupakan salah satu komoditas ekspor Indonesia, yang 
memiliki nilai ekonomis tinggi. Harga benih yang pada awalnya berkisar antara Rp.1.500-Rp.2.500/ekor, dengan ukuran sekitar 2-3 cm. Harga terus meningkat hingga Rp.17.000-Rp.20.000/ekor (Erlania et al., 2014). Peningkatan harga tersebut menyebabkan lobster menjadi salah satu target tangkapan utama nelayan, untuk memenuhi permintaan masyarakat yang terus mengalami peningkatan dari tahun ke tahun. Hal inilah yang dapat berpengaruh terhadap keseimbangan populasi dan ketersediaan lobster di alam, sehingga kegiatan budidaya lobster perlu dikembangkan.

Perairan pada Pulau Lombok terdapat 5 (lima) jenis lobster, yaitu: lobster pasir (Panulirus homarus), lobster bambu biru (Panulirus versicolor), lobster mutiara (Panulirus ornatus), lobster bambu macan (Panulirus penicillatus), dan lobster bambu merah (Panulirus longipes) (Junaidi, 2018). Lobster yang banyak dibudidayakan di perairan Pulau Lombok yaitu, jenis lobster pasir (Panulirus homarus),karena hasil tangkapan bibit alam jenis lobster pasir lebih banyak dibanding dengan jenis lobster lainnya.

Ikan rucah merupakan salah satu hasil tangkapan yang berada di Desa Tanjung Luar, yang biasa digunakan sebagai pakan untuk lobster. Selain harga yang murah, ikan rucah juga memiliki kandungan protein sebesar $57 \%$, lemak $13,65 \%$, serat kasar $0,17 \%$ dan air $7,69 \%$ (Herlinah dan Gunarto., 2015). Namun yang menjadi kendalanya yaitu ketersedian ikan rucah yang hanya ada pada musim tertentu. Menurut Arlian et al. (2017), pada bulan Oktober hingga bulan Maret terjadi curah hujan yang cukup tinggi, sehingga menyebabkan hasil tangkapan ikan rucah menurun. Maka dari itu, perlu dicari alternatif pakan yang tersedia setiap saat dan memiliki kandungan nutrisi yang sesuai untuk pertumbuhan benih lobster pasir (Panulirus homarus).

Kulit sapi merupakan salah satu alternatif pakan, diduga dapat menggantikan peran ikan rucah sebagai pakan lobster. Kulit sapi memiliki keunggulan, yaitu selalu tersedia tanpa bergantung pada musim. Selain itu, kulit sapi juga memiliki kandungan protein yang lebih tinggi mencapai 84,90\% (Harlinah dan Gunarto., 2015). Kandungan protein yang tinggi akan dapat memicu pertumbuan benih lobster dengan sangat cepat, terutama pada fase benih yang merupakan fase kritis untuk benih lobster pasir. Halver (1989) dalam Makasangkil et al. (2017), menyatakan bahwa protein yang dicerna akan digunakan oleh organ dan jaringan dalam pembentukan protein baru, yang berfungsi untuk pertumbuhan atau menggantikan protein yang ada sebagai fungsi pemeliharaan. Pemberikan pada pakan kulit sapi, diharapkan pertumbuhan benih lobster pasir akan lebih cepat dan tingkat kelagsungan hidupnya tinggi.

Melihat besarnya potensi kulit sapi sebagai pakan alternatif pengganti ikan rucah, maka penelitian ini dilakukan untuk mengetahui pengaruh pemberian pakan kulit sapi terhadap pertumbuhan dan kelangsungan hidup benih loster pasir (Panulirus homarus).

\section{Metode \\ Waktu dan Tempat}

Penelitian dilaksanakan di Desa Tanjung Luar, Kecamatan Keruak, Kabupaten Lombok Timur, Nusa Tengara Barat. Penelitian dilakukan selama 60 hari, mulai dari tanggal 1 Mei 2019 - 29 Juni 2019.

\section{Metode Penelitian}

Metode yang digunakan adalah metode eksperimental. Menggunakan Rancangan Acak Kelompok (RAK) dengan 5 (lima) perlakuan dan 3 (tiga) kelompok, sehingga diperoleh 15 unit percobaan. Benih lobster uji yang digunakan adalah benih lobster pasir dengan berat rata-rata \pm 3 gram, \pm 5 gram dan \pm 7 gram sebanyak 180 ekor dan padat tebar sebanyak 12 ekor/wadah. Pakan yang 
diberikan berupa ikan rucah dan kulit sapi yang dirubus sebanyak $5 \%$ dari berat tubuhnya. Pakan diberikan 2 kali sehari, yaitu: pada pukul 06.00 WITA dan pukul 18.00 WITA.

Parameter yang di uji secara statistik adalah pertumbuhan mutlak, laju pertumbuhan spesifik, rasio konversi pakan dan tingkat kelangsungan hidup.

\section{Analisa data}

Data yang diperoleh dianalisa menggunakan univerate dengan taraf nyata $5 \%$ untuk mengetahui pengaruh perlakuan. Apabila dari analisis statistik diketahui bahwa perlakuan menunjukkan pengaruh Tabel 1. Hasil analisis keragaman pengaruh pemberian pakan kulit sapi terhadap parameter

\begin{tabular}{|c|c|c|c|c|c|}
\hline \multirow{2}{*}{ Parameter } & \multicolumn{5}{|c|}{ Perlakuan } \\
\hline & P1 & P2 & P3 & P4 & P5 \\
\hline $\mathrm{G}(\text { gram })^{\mathrm{s}}$ & $4,82 \pm 0,47^{a b}$ & $5,61 \pm 0,32^{a b}$ & $9,98 \pm 0,81^{\mathrm{c}}$ & $6,73 \pm 0,65^{b}$ & $3,85 \pm 1,30^{\mathrm{a}}$ \\
\hline SGR $(\%)^{\mathrm{s}}$ & $1,19 \pm 0,35^{\mathrm{ab}}$ & $1,33 \pm 0,43^{\mathrm{a}}$ & $1,93 \pm 0,47^{b}$ & $1,49 \pm 0,38^{\mathrm{ab}}$ & $1,04 \pm 0,59^{\mathrm{a}}$ \\
\hline $\mathrm{FCR}^{\mathrm{ns}}$ & $0,61 \pm 0,49$ & $0,44 \pm 0,14$ & $0,85 \pm 0,17$ & $0,96 \pm 0,14$ & $1,06 \pm 0,76$ \\
\hline $\mathrm{SR}(\%)^{\mathrm{ns}}$ & $86,11 \pm 4,82$ & $91,67 \pm 0,00$ & $94,45 \pm 4,81$ & $91,67 \pm 0,00$ & $91,67 \pm 8,54$ \\
\hline
\end{tabular}

Keterangan : s (significant): Berpengaruh nyata. ns (not significant): Tidak berpengaruh nyata. P1: $100 \%$ ikan rucah. P2: $75 \%$ ikan rucah $+25 \%$ kulit sapi. P3: $50 \%$ ikan rucah $+50 \%$ kulit sapi. P4: $25 \%$ ikan rucah $+75 \%$ kulit sapi. P5: $100 \%$ kulit sapi

Pertumbuhan pertambahan berat dalam suatu waktu. Pertumbuhan dipengaruhi oleh beberapa faktor yaitu faktor internal dan faktor eksternal. Faktor internal yaitu: keturunan, sex, umur, parasit dan penyakit. Sedangkan faktor eksternal yang utama yaitu: makanan dan suhu perairan (Effendi, 2002 dalam Rihardi et al., 2013). Hasil penelitian menyatakan bahwa pertumbuhan mutlak dan laju pertumbuhan spesifik tertinggi terjadi pada P3 (50\% ikan rucah + $50 \%$ kulit sapi). Hal ini diduga karena dalam pakan tersebut terdapat kandungan nutrisi yang seimbang sehingga dapat memenuhi kebutuhan nutrisi yang dibutuhkan oleh benih lobster pasir untuk pertumbuhannya. Nutrisi merupakan substansi organik yang terkandung dalam pakan. Apabila pakan yang diberikan kepada udang pemeliharaan mempunyai yang berbeda nyata dilanjutkan dengan uji Tukey dengan taraf nyata 5\% untuk mengetahui perlakuan yang terbaik.

\section{Hasil}

Pemberian pakan kulit sapi dengan persentase yang berbeda berpengaruh nyata $(\mathrm{P}<0,05)$ terhadap pertumbuhan mutlak dan laju pertumbuhan spesifik, namun tidak berpengaruh nyata $(\mathrm{P}>0,05)$ terhadap rasio konversi pakan dan tingkat kelangsungan hidup (Tabel 1). 
Pemberian pakan 100\% kulit sapi (P5) menunjukkan nilai pertumbuhan mutlak dan laju pertumbuhan spesifik terendah. Kulit sapi rebus memiliki kandungan protein mencapai 36\% (Nadia, 2005). Hal ini menunjukkan kandungan pada kulit sapi kurang memenuhi kebutuhan benih lobster pasir, sehingga energi yang diperoleh dari pakan hanya cukup untuk menopang kehidupan benih lobster pasir, tetapi tidak cukup memberikan pertumbuhan dengan baik, akibatnya pertumbuhan yang dihasilkan juga rendah. Hal ini sesuai dengan pernyataan Ikhsan et al. (2019) lobster dapat tumbuh dengan baik jika protein yang diperoleh berada pada dosis yang optimum, karena protein yang berlebihan akan dibuang melalui urine dan proses tersebut memerlukan energi untuk bisa berjalan, sehingga energi yang seharusnya digunakan untuk tumbuh dialihkan ke proses tersebut dan membuat pertumbuhan menjadi lambat.

Rasio konversi pakanmerupakan banyaknya jumlah pakan yang diberikan selama pemeliharaan untuk menujang pertambahan berat benih lobster pasir. Hasil analisis ragam menunjukkan bahwa pemberian pakan yang berbeda tidak berpengaruh nyata $(\mathrm{P}>0,05)$ terhadap rasio konversi pakanbenih lobster pasir, sehingga tidak dapat disimpulkan perlakuan yang lebih baik maupun yang lebih buruk, melainkan kecenderungan saja. Pemberian pakan $100 \%$ kulit sapi (P5) dapat dikatakan cenderung memiliki efisensi pakan yang lebih dari P1, P2, P3 dan P4. Menurut Daris dan Febri (2013), ketersediaan pakan dan kemampuan lobster untuk memanfaatkan atau mencerna pakan akan menentukan pertumbuhan lobster. Nilai konversi pakan berbanding terbalik dengan pertambahan bobot, sehingga semakin rendah nilainya maka semakin efisien biota dalam memanfaatkan pakan yang dikonsumsinya untuk pertumbuhan (Riani et al., 2012).
Nilai konversi pakan yang rendah menunjukkan bahwa pakan yang diberikan hampir sepenuhnya dimanfaatkan. Sehingga, semakin rendah konversi pakan, maka pakan yang diberikan semakin efisien digunakan untuk pertumbuhan. Sebaliknya, semakin tinggi nilai konversi pakan, maka pakan yang diberikan semakin tidak efisien digunakan untuk pertumbuhan (Saltin et al., 2016).

Tingkat kelangsungan hidup benih lobster pasir adalah nilai persentase jumlah benih lobster pasir yang hidup selama pemeliharaan. Hasil analisis ragam menunjukkan bahwa pemberian pakan yang berbeda tidak berpengaruh nyata $(\mathrm{P}>0,05)$ terhadap kelangsungan hidup benih lobster pasir. Pada P3 tingkat kelangsungan hidup mencapai 94,45\% , kemudian P2, P3 dan P4 memiliki tingkat kelangsungan hidup yang sama yaitu mencapai 91,67\%, sedangkan P1 sebesar $86,11 \%$. Benih lobster pasir yang mati pada penelitian diduga karena terjadinya kanibalisme. Kendala yang sering terjadi dalam budidaya benih lobster ialah kanibalisme pada benih lobster pasir. Benih lobster pasir yang mengalami moulting akan menjadi sasaran kanibalisme. Hal ini sesuai dengan pernyataan Rihardi et al. (2013) kanibalisme terjadi pada lobster yang berukuran kecil dan lobster yang mengalami pergantian kulit atau moulting. Karena pada saat moulting lobster akan mengeluarkan aroma yang khas sehingga menarik lobster yang lain dan terjadi pemangsa.

Kualitas air merupakan salah satu faktor penting dalam menunjang pertumbuhan dan kelangsungan hidup benih lobster pasir. Selama penelitian telah dilakukan pengukuran terhadap beberapa parameter kualitas air diantaranya: suhu, $\mathrm{pH}$, salinitas dan DO. Dari hasil pengukuran kualitas air didapatkan bahwa kualitas perairan dalam masa penelitian masih dalam taraf normal dan berada dalam kisaran yang baik. 
Suhu pada saat pemeliharaan benih lobster pasir berkisar antara $28-29{ }^{\circ} \mathrm{C}$, dimana suhu tersebut termasuk suhu yang optimal untuk budidaya lobster. Menurut Kordi dan Tancung (2017) dalam Ikhsan et al. (2019) suhu optimal untuk pemeliharaan lobster air laut antara 23-32 ${ }^{\circ} \mathrm{C}$.

Pengukuran salinitas didapatkan hasil salinitas perairan berkisar 32-33 ppt, dimana salinitas ini layak untuk budidaya benih lobster pasir. Menurut Phillips dan Kittaka (2000) dalam Prariska (2018) bahwa lobster memiliki toleransi salinitas yaitu $25-45$ ppt.

Selama penelitian $\mathrm{pH}$ perairan berkisar antara 8-8,06, yang merupakan $\mathrm{pH}$ yang layak untuk budidaya benih lobster pasir. Menurut Wickins dan Lee (2002) dalam Prariska (2018), nilai $\mathrm{pH}$ yang optimal pada pembesaran lobster pasir adalah 8,0-8,5 sedangkan $\mathrm{pH}$ yang optimal untuk biota laut adalah 7,6-8,7 (Kordi 2011).

Oksigen terlarut (DO) perairan selama penelitian berkisaran 5-6 ppm, yang merupakan oksigen terlarut yang layak untuk budidaya benih lobster pasir. Menurut Saparinto (2014) dalam Putri et al. (2018) oksigen terlarut yang dibutuhkan pada lobster air laut di KJA adalah >4 ppm.

\section{Kesimpulan}

Berdasarkan hasil penelitian ini dapat disimpulkan bahwa pemberian pakan kulit sapi memberikan pengaruh nyata $(\mathrm{P}<0,05)$ terhadap pertumbuhan mutlak dan laju pertumbuhan spesifik pada benih lobster pasir (Panulirus homarus), namun tidak berpengaruh terhadap rasio konversi pakan dan tingkat kelangsungan hidup.

\section{Daftar Pustaka}

Adiyana K dan Supriyono E. 2015.Efisiensi Daya Listrik dan Kondisi Oksigen Terlarut Pada Pemeliharaan Post larva Udang
Vaname Litopenaeus vannamei Menggunakan Sumber Energi Surya. Pusat Pengkajian Perekayasaan Teknologi Kelautan Perikanan-Balitbang-KKP.

Departemen Budidaya Perairan Fakultas Perikanan dan Ilmu Kelautan IPB. Bogor.

Alfin., Agus, K., dan Muhaimin, H. 2017. Substitusi Minyak Ikan dengan Minyak Jagung dalam Pakan Terhadap Pertumbuhan dan Kelangsungan Hidup Lobster Air Laut (Panulirus sp.). Media Akuatika. Fakultas Perikanan dan Ilmu Kelautan Universitas Halu Oleo. Sulawesi Tenggara. 2 (1): 270-278.

Anggraini W., Abidin Z dan Waspodo S. 2018. Pengaruh Pemberian Pakan Keong Mas Terhadap Pertumbuhan Dan Kelangsungan Hidup Lobster Pasir (Panulirus homarus). J urnal Perikanan. Program Studi Budidaya Perairan, Universitas Mataram. 8 (2): 20-29.

Arlian B., Miswar E dan Musman M. 2017. Komparasi Finansial Hasil Tangkapan Pertahun Di Pantai Barat Selatan Dan Pantai Timur Utara Provinsi Aceh. Jurnal Ilmiah Mahasiswa Kelautan dan Perikanan Unsyiah. Program Studi Pemanfaatan Sumberdaya Perikanan, Fakultas Kelautan dan Perikanan, Universitas Syiah Kuala. Darussalam, Banda Aceh. 2(1): 20-25.

Cokrowati N., Pujiati U dan Sarifin. 2012. Perbedaaan Padat Tebar Terhadap Tingkat Pertumbuhan Dan Kelangsungan Hidup Post Peurulus Lobster Pasir (Panulirus homarus) pada Bak Terkontrol. Jurnal 
Kelautan. Program Studi Budidaya Perairan, Universitas Mataram.

Daris L dan Febri. 2013. Pengaruh Dosis Pakan Buatan Yang Berbahan Baku Lokal Dalam Pakan Pembesaran Lobster Air Tawar Capit Merah (Cherax quadricarinatus). Jurnal Balik Diwa. Makassar. 4 (1): 1-7

Erlina., Nyoman I. R dan Sugama K. 2014. Dinamika Kelimpahan Benih Lobster (Panulirus spp.) Di Perairan Teluk Gerupuk, Nusa Tenggara Barat: Tantangan Pengembangan Teknologi Budidaya Lobster. J. Ris. Akuakultur. Pusat Penelitian Dan Pengembangan Perikanan Budidaya. 9 (3): 475-486.

Firdus dan Z. A Muchlisin. 2005. Pemanfaatan Keong Mas (Pomacea canaliculata) sebagai Pakan Alternatif dalam Budidaya Ikan Kerapu Lumpur (Epinephelus tauvina). ENVIRO. FMIPA Universitas Syiah Kuala, Banda Aceh. 5 (1): 64-66.

Hargiyanto I. T., Satria F., Prasetyo A. P dan Fauzi M. 2013. Hubungan Panjang-Berat dan Faktor Kondisi Lobster Pasir (Panulirus homarus) Di Perairan Yogyakarta dan Pacitan. Bawal. 5 (1): 41-48.

Herlina S. 2016. Pengaruh Pemberian Jenis Pakan yang Berbeda Terhadap Pertumbuhan dan Kelangsungan Hidup Benih Ikan Gabus (Channa striata). Jurnal Ilmu Hewani Tropika. Program studi Budidaya Perairan, Fakultas Perikanan dan Ilmu Kelautan, Universitas Darwan Ali, Seruyan.

Hermawan D., Mustahal dan Kuswanto. 2015. Optimasi Pemberian Pakan Berbeda Terhadap Pertumbuhan
Dan Kelangsungan Hidup Ikan Kerapu Macan (Epinephelus fuscoguttatus). Jurnal Perikanan dan Kelautan. Jurusan Perikanan, Fakultas Pertanian, Universitas Sultan Ageng, Tirtayasa. 5 (1): 5764.

Junaidi M., Cokrowati N dan Abidin Z. 2011. Tingkah laku induk betina selama proses pengeraman telur dan perkembangan larva lobster pasir (Panulirus homarus). Jurnal Akuatikan. 2 (1): 26-36.

Junaidi M. 2018. Budidaya Lobster di Perairan Pulau Lombok. Pustaka Bangsa. Mataram.

Makasangkil L., Salindeo I. R. N dan Lumenta C. 2017. Pengaruh perbedaan jenis pakan terhadap pertumbuhan lobster laut, Panulirus versicolor. Budidaya Perairan. Program Studi Budidaya Perairan FPIK UNSRAT, Manado. 5 (3): 110.

Nadia L. 2005. Nutrisi dan Beberapa Kriteria Halal Kerupuk Kulit Jangek. Jurnal Matematika, Sains, Teknologi. Universitas Terbuka. Sumatra Barat. 6 (2): 100-107.

Nisa A., Lumbessy S. Y dan Kartamihardja U. K. A. 2013. Efektivitas Pakan Bioaktif terhadap Pertumbuhan, Kelangsungan Hidup, dan Biomassa Akhir Juvenil Lobster Pasir (Panulirus homarus) yang Dipelihara di Dalam Wadah Terkontrol. Jurnal Perikanan Unram. Program Studi Budidaya Perairan, Universitas Mataram.

Pratiwi R., Supriyono E Dan Widanarni. 2016. Total Hemosit, Glukosa Hemolim, Dan Kinerja Produksi Lobster Pasir Panulirus homarus yang Dibudidaya Menggunakan 
Sistem Kompartemen Individu. Jurnal Ilmu Dan Teknologi Kelautan Tropis. 8 (1): 321-333.

Putra A. T., Fitri A. D. P dan Pramonowibowo. 2013. Pengaruh Perbedaan Bahan Bubu dan Jenis Umpan Terhadap Hasil Tangkapan Lobster Air Tawar (Cherax quadricarinatus) Di Rawa Pening Semarang. Journal Of Fisheries Resources Utilization Management and Technology. Fakultas Perikanan dan Ilmu Kelautan Universitas Diponegoro. 2 (3): 243252.

Putri L. D., Nurliah., Adhita D. A dan Eka L. C. 2018. Parameter Kualitas Air Dalam Mendukung Kegiatan Budidaya Di Kawasan Teluk Jor, Kabupaten Lombok Timur. PKMCSR. Universitas mataram.

Riani H., Rostika R dan Lili W. 2012. Efek Pengaruh Pakan Terhadap Pertumbuhan Udang Vaname (Litopenaeus vannamei) PL-21 yang diberi Bioflok. Jurnal perikanan dan kelautan. Fakultas perikanan dan ilmu kelautan unpad. 3 (3): 270-211.

Rihardi I., Amir S dan Abidin Z. 2013. Pertumbuhan Lobster Air Tawar (Cherax quadricarinatus) pada Pemberian Pakan dengan Frekuensi yang Berbeda. Jurnal Perikanan Unram. Program Studi Budidaya Perairan. Mataram. 1 (2): 29-35.

Sadinar B., Samidjan I dan Rachmawati D. 2013. Pengaruh Perbedaan Dosis Pakan Keong Mas dan Ikan Rucah Pada Kepiting Bakau. (Scylla paramamosain) Terhadap Pertumbuhan dan Kelulushidupan dengan Sistem Battery Di Tambak Tugu, Semarang. Journal of
Aquaculture Management and Technology. Budidaya Perairan. universitas Diponegoro. 2 (4): 8493.

Saputra S. W. 2009. Status Pemanfaatan Lobster (Panulirus sp) di Perairan Kebumen. Jurnal Saintek Perikanan. Program Studi Manajemen Sumberdaya Perairan. Jurusan Perikanan Fakultas Perikanan dan Ilmu Kelautan Universitas Diponegoro. Semarang. 4 (2): 10-15.

Sasmitaloka K. S., Miskiyah dan Juniawati. 2017. Kajian Potensi Kulit Sapi Kering Sebagai Bahan Dasar Produksi Geelatin Halal. Buletin Peternakan. Balai Besar Litbang Pascapanen Pertanian. Bogor. 41 (3): 328-337.

Setyanto A., Rachman N. A dan Yulianto E. S. 2018. Distribusi dan Komposisi Spesies Lobster yang Tertangkap di Perairan Laut Jawa bagian Jawa Timur, Indonesia. Jurnal Perikanan Universitas Gadjah Mada. 20 (2): 49-55

Sholichin I., Haetami K dan Suherman H. 2012. Pengaruh Penambahan Tepung Rebon pada Pakan Buatan Terhadap Nila Chroma Ikan Mas Koki (Carassius auratus). Jurnal perikanan dan kelautan. Fakultas perikanan dan ilmu kelautan. Universitas padjadjaran. 3 (4): 185190.

Sukamto., Muryanto $\mathrm{T}$ dan Kusiani $\mathrm{H}$. 2017. Teknik Identifikasi Jenis Kelamin Lobster Berbais Ciri-ciri Morfologi. Teknisi Litkayasa Pada Balai Penelitian Pemulihan dan Konservasi Sumber Daya Ikan. 
Jurnal Perikanan (2019) Volume 9. No. 2 : 144-152

DOI : https://doi.org/10.29303/jp.v9i2.160

Suriadi S. L., Yusnaini dan Agus K. 2017. Perairan. Universitas Halu Oleo. 2 Pengaruh Jenis Pakan Segar (2): 360-367.

Terhadap Pertumbuhan Biomassa Calon Induk Lobster Batik (Panulirus Longipes). Media Akuatika. Program Studi Budidaya

WWF-Indonesia. 2015. Perikanan Lobster Laut. Panduan Penangkapan dan Penanganan. Jakarta Selatan. 